\title{
THE THERMAL POTENTIAL OF AN EARTH TUBE HEAT EXCHANGER SYSTEM IN AIR TEMPERATURE MODERATING
}

\section{Said E. AbouZaher ${ }^{1}$, El-said M. Khalifa ${ }^{2}$ and Yahya T. Shalaby ${ }^{3}$}

\section{ABSTRACT}

The potential of earth tube heat exchangers in tempering ventilation air in delta region was studied experimentally by using two diffident systems. The two systems were installed at the research farm, faculty of agriculture, Kafrelsheikh University (31.07 $N$ and $\left.30.57^{\circ} \mathrm{E}\right)$, Kafrelsheikh governorate, Egypt. The first system (S1) consisted of one pipe with inner diameter of $10.85 \mathrm{~cm}$. The second system (S2) consisted of two coaxial pipes the first pipe with inner diameter of $10.85 \mathrm{~cm}$ surrounded by the other one with inner diameter of $16.2 \mathrm{~cm}$ and the annular space between them filled by water and sealed. The length of both systems was $12 \mathrm{~m}$ and buried at a depth of $75 \mathrm{~cm}$ within two ditches $5 \mathrm{~m}$ apart and refilled with earth. The ambient air was blown by a 0.75 $k W$ blower to pass through the two buried systems. The systems were operated during cooling and heating modes at four operating durations and five air velocities. It was found that, the maximum temperature reduction and rise were $12.65{ }^{\circ} \mathrm{C}$ at air velocity $1.8 \mathrm{~m} / \mathrm{s}, 12$ hours operating duration and $6.27{ }^{\circ} \mathrm{C}$ at velocity $3.7 \mathrm{~m} / \mathrm{s}, 12$ hours operating duration under cooling and heating modes for $S 1$ respectively. Maximum thermal energy rate removed during cooling mode was 679.9 W for S2 at air velocity $9.7 \mathrm{~m} / \mathrm{s}$ and 22 hours operating duration and the corresponding COP was 3.96. The maximum thermal energy rate added during heating mode was 629.7 W for $S 1$ at air velocity $9.7 \mathrm{~m} / \mathrm{s}, 12$ hours operating duration and the corresponding COP was 3.67. Both systems contribute in air temperature control which declares in diminishing its amplitude. It was found that when the air velocity (mass flow rate) increase the thermal energy rate removed / added increases although the

\footnotetext{
${ }^{1}$ Assistant prof., Agric. Eng. Dept. Faculty of Agric, Kafrelsheikh University. Egypt.

${ }^{2}$ Prof., Agric. Eng. Dept. Faculty of Agric, Kafrelsheikh University., Egypt.

${ }^{3}$ Graduate Student, Agric. Eng. Dept. Faculty of Agric, Kafrelsheikh University. Egypt. Saidkhalifa2002@gmail.com
} 
temperature reduction / rise decreases. This was because of the effect of increasing mass flow rate was predominant than the effect of temperature reduction/ rise in thermal energy rate exchanged evaluation. Key words: Earth tube, thermal potential, earth to air heat exchanger.

\section{INTRODUCTION}

$\mathrm{M}$ any of agricultural structures need to modify the ventilation air temperature. This modification involves cooling or heating processes. However, just ventilation air tempering or moderating may be adequate in some applications. Traditional systems accompanied with some problems such as increasing energy prices and the tendency to diminish specifically the petrol based ones, agriculture structures may locate in remote areas which need for non-traditional energy source. Existing of a dual action - in terms of heating and cooling - systems which required in agricultural structures activities should be given more attention. Non-desired particles such as exhaust gases in heating facilities and high humidity in some cooling systems (evaporative cooling) may occur with the numerous systems. Therefore search on some non-traditional heating and cooling systems is virtually needed. Because of the stability of underground temperature at depth exceeds than one meter with small seasonal variation, this phenomena was exploited in space heating and cooling processes in winter and summer respectively. This can be accomplished by the aid of a buried tube represents a heat exchanger through which the ambient air passes and the heat exchanged from the air to earth in summer and from the earth to air in winter. Such a well known system called earth tube heat exchanger (ETHE).

Mihalakakou et al. (1994) and Mihalakakou (2003) concluded from a simulation study that the earth-to-air heat exchanger can provide an effective method for space heating and cooling in Mediterranean climates. Kassem (1999) carried out an experimental study on the effectiveness of earth tube heat exchanger with two different structural frames (gable- even- span and modified quonset) of the greenhouses in Egypt. He used a galvanized iron earth-tube heat exchanger with $1 \mathrm{~mm}$ thick, $50 \mathrm{~m}$ long, $0.14 \mathrm{~m}$ diameter and buried at $2 \mathrm{~m}$ depth. He found that the interior ambient air temperatures of conditioned greenhouses were 
around the optimum one but unconditioned greenhouses differ than optimum temperature in a large range. Pfafferott (2003) compared between thermal performances of three EAHXs Earth to Air Heat Exchanger located in Germany differ in total surface area, air flow rate, control system and system configuration. He concluded that the energy gain is dependent on climate and operation duration. In addition high energy gains were achieved at the high temperature difference between the inlet air and ground. Ghosal et al. (2004), Ghosal and Tiwari (2006) carried out experimental studies to validate a model and to evaluate the performance of an earth to air heat exchanger (EAHE) in India. They used a PVC pipe of $39 \mathrm{~m}$ length and $0.06 \mathrm{~m}$ diameter, at a burying $1 \mathrm{~m}$ depth. An average of temperature rise and reduction ranged from $6-8$ and from $3-6{ }^{\circ} \mathrm{C}$ for winter and summer respectively were achieved. AlAjmi et al. (2006) concluded from their simulation study that the incorporation of an EAHE system with a building can reduce the cooling load of the building by $1693 \mathrm{kWh}$ and a saving of $30 \%$ over the summer period considered under India condition. Badescu (2007) pointed out that the ground heat exchanger is a reliable device but the heating flux it provides during the cold season is rather small under Germany conditions. Wu et al. (2007), Darkwa et al. (2011) conducted experimental studies to verify a model and to evaluate the performance of an ETHE in China. They found that the ETHE system can reduce the energy consumption for cooling and heating buildings in china. Lee and Strand (2008), Ascione et al. (2011) used a validated model to predict the thermal performance of ETHE integrated to a building at different places. They concluded that the weather and soil conditions should be considered in order to determine whether or not earth tubes should be used in particular locations. Bansal et al. $(2009,2010)$ carried out an experimental study in India to validate a model and to calculate total hourly heating and cooling obtained from an ETHE system. They used two horizontal cylindrical pipes of $0.15 \mathrm{~m}$ inner diameter with a buried length of $23.42 \mathrm{~m}$, made of PVC and mild steel pipes and buried at a depth of $2.7 \mathrm{~m}$ in a flat land with dry soil. They found that the total hourly heating and cooling obtained varied between $0.423-0.846$ and 1.2 - 3.1 MW h respectively. Yoon et al. (2009) carried out an 
experimental study in Japan to verify a model and to evaluate the performance of heating, ventilating and air-conditioning (HVAC) system. They installed nine PVC pipes at 2.25 depth with a diameter of $0.5 \mathrm{~m}$ and differ in length. The maximum Air velocity in tube was $2.57 \mathrm{~m} / \mathrm{s}$. They found the maximum air temperature difference between the inlet and the outlet was $7.0{ }^{\circ} \mathrm{C}$ in winter and $8.3{ }^{\circ} \mathrm{C}$ in summer. The average cool/heat transfer rates were 30.3 and $23.2 \mathrm{MJ} / \mathrm{h}$, respectively. Ozgener and Ozgener.(2010 a, b) investigated the performance of a passive heated greenhouse in Turkey using a horizontal galvanized U-bend buried pipe at about $3 \mathrm{~m}$ in depth with $56 \mathrm{~cm}$ diameter $47 \mathrm{~m}$ long as an underground air tunnel (UAT) and connected to the greenhouse. The obtained average temperature difference of the air between the outlet and inlet of the UAT was approximately $2.3^{\circ} \mathrm{C}$. The maximum heating capacity of the system was $4.5 \mathrm{~kW}$ with an average of $3.77 \mathrm{~kW}$. The maximum COP of the UAT system is about 6.24 with an average of 4.95. In addition, Ozgener et al.(2011) investigated the performance of the previously mentioned system in cooling mode. They found that the maximum cooling capacity of the system was $16.93 \mathrm{~kW}$ and the daily variation of the system COP was in the range of $0.98-10.88$. Vaz et al. (2011) conducted an experiential study to validate a model and to evaluate an earth- air - heat exchanger (EAHE) in Brazil. They found that the air heated by higher than $8.0^{\circ} \mathrm{C}$ in buried ducts. While cooled by approximately $3.0^{\circ} \mathrm{C}$ for a depth of $2.0 \mathrm{~m}$ and $4.0^{\circ} \mathrm{C}$ for a depth $3.0 \mathrm{~m}$ burying depths. Mongkon et al.( 2013) used iron horizontal earth tube with length $38.5 \mathrm{~m}$, diameter $0.08 \mathrm{~m}$ buried at a depth of $1 \mathrm{~m}$ for cooling a greenhouse in Thailand during summer and winter. A constant air flow rate of about $216 \mathrm{~kg} / \mathrm{h}$ was used. They concluded that the system was efficient at a percentage $74.84 \%$ and $45.48 \%$ for summer and winter respectively. Duby et al.(2016) analyzed the performance of earth tube heat exchanger (ETHE) and investigated the performance under cooling mode. They found that the cooling effect in terms of temperature reduction decreased and in terms of thermal energy rate removed increased by increasing air flow velocity. They added that the COP increased by increasing air velocity as well. Accordingly earth tube heat exchanger (ETHE) system may be considered a respected one to enhance the thermal level of the ventilation 
air all over the world. Therefore the main objective of the present study was to investigate the thermal potential of an earth tube heat exchanger system in tempering or moderating ventilation air in delta region. The specific objectives were as follow:-

1- Investigation of the feasibility of using an earth tube system in cooling and heating modes.

2- Comparing between two systems $\mathrm{S} 1$ and $\mathrm{S} 2$ differ in their configuration. First (S1) permits heat transfer between air and soil across the tube wall material (PVC). The second system (S2) provides an additional water layer for the heat pass to permit the heat transfer across both the tube wall material (PVC) and water layer in addition to another tube wall material (PVC). This second system (S2) was suggested based on the higher heat capacity of water compared to heat for soil which may lead to extend the effective action duration of the ETHE.

3- Studying the effect of air flow rate in terms of air velocity on the air temperature reduction / rise and on the heat removed / added from / to air for both systems. Air velocities of 1.8, 3.7, 5.7, 7.7 and $9.7 \mathrm{~m} / \mathrm{s}$ were investigated.

4- Studying the effect of operating duration on the outlet air temperature and on the heat remove / added from / to air for both systems. Operating duration of $6,9,12,22$ hours were investigated.

5- Exploring the capability of ETHE system to enhance the air temperature control level.

\section{MATERIALS AND METHODS}

Two experimental systems were installed during the period of 1/7/2014 to $14 / 8 / 2014$ at the research farm, faculty of agriculture, Kafrelsheikh University $\left(31.07^{\circ} \mathrm{N}\right.$ and $\left.30.57^{\circ} \mathrm{E}\right)$, Kafrelsheikh governorate, Egypt. The main experiments were carried out during the period of 15/8/2014 to $30 / 9 / 2014$ for cooling mode and during the period of $4 / 1 / 2015$ to 27 /2/2015 for heating mode.

\section{Materials:}

\section{Experimental system:}

Experimental system consisted of three horizontal pipes, four vertical pipes and a transverse horizontal pipe (all made of PVC). A blower, two 
air valves and timer were also used to manipulate air flow through the system. Table 1 shows the technical specifications and functions of these main components.

Two ditches have $0.75 \mathrm{~m}$ depth and $5 \mathrm{~m}$ apart were excavated. Because of the higher soil water level it was drawn out by using a suction pump. To construct the first investigated system (S1), one horizontal PVC pipe (P1) was connected to two vertical pipes by the aid of elbows and sealed at both ends then laid and buried on the bottom surface of one ditch. Regarding the second investigated system (S2), two coaxial pipes P1 and $\mathrm{P} 2$ having an annular space were prepared, P1connected to two vertical pipes and the hole system (S2) was buried in the same manner as S1. Then the annular space was filled with water and sealed (Figure 1). The transverse horizontal pipe on the ground surface was divided to two equivalent parts and each air valve was fixed at the midpoint of each part. Then the end of each part was connected to one vertical pipe of both systems S1 and S2. Then the blower was attached to the middle of the transverse horizontal pipe on the ground surface (Figure 2). A circular gate was constructed on the suction side (inlet) of the blower to manipulate air flow rate, in turn adjust and maintain the predetermined air velocity. Finally the whole experimental system was checked to be ready to run experiments. Figure 3 illustrates a schematic drawing for the whole experimental system.

\section{Instrumentation:}

Temperature and relative humidity were measured as the main parameters. , Air velocity and Electrical current were detected and monitored as well. Regarding the temperature and relative humidity four locally manufactured units were constructed by using LM35 sensor for temperature and KY-015 sensor for relative humidity. The manufactured units were calibrated against an ordinary thermometer for temperature and against thermohygrometer KlimaLogg (Range: 1 - 99\%, Accuracy: +/- 3\%) for relative humidity. The calibration process revealed deviations ranged from 0.2 to $2.4{ }^{\circ} \mathrm{C}$ with the average of $1.56{ }^{\circ} \mathrm{C}(\mathrm{SD}=0.59)$, and from 3 to $11 \%$ with the average of $6.89 \%(\mathrm{SD}=2.07)$ for temperature and relative humidity respectively. However regarding temperature two sensors were used to measure inlet air temperature $\left(\mathrm{T}_{\mathrm{i}}\right)$ for both systems $\mathrm{S} 1$ and $\mathrm{S} 2$, in addition to anther 
two sensors for measuring outlet air temperature for both systems S1 and S2 $\left(\mathrm{T}_{\mathrm{o}}\right)$ as well, one sensor was used to measure the ambient air temperature., another one sensor was employed to measure the temperature of air exiting the blower. Regarding relative humidity two humidity sensors were used to measure inlet air humidity for both systems S1 and S2, in addition to another two sensors were employed to measure outlet air humidity for both systems as well. Air velocity was measured by using a vane anemometer (model AM-4838) at the inlet and outlet vertical pipes of both systems and the average value was then taken. Electrical current required to operate the blower was measured by using a Digital multimeter (model M-890 $\mathrm{C}^{+}$) at each air velocity.

Table 1 : Technical specifications and functions of the experimental system main components.

\begin{tabular}{|c|c|c|}
\hline Component & Specification & Functions \\
\hline $\begin{array}{l}\text { Two PVC horizontal } \\
\text { pipes }\left(p_{1}\right)\end{array}$ & $\begin{array}{l}\text { Length }: 12 \mathrm{~m} \\
\text { Inner diameter : } 10.85 \mathrm{~cm} \\
\text { Thickens : } 2.8 \mathrm{~mm} \\
\text { Burying depth }: 0.75 \mathrm{~m}\end{array}$ & $\begin{array}{l}\text { Air pass and it is considered } \\
\text { the main part in conjunction } \\
\text { with the contacted soil layer in } \\
\text { such earth tube heat exchanger } \\
\text { (ETHE) system. }\end{array}$ \\
\hline $\begin{array}{l}\text { One PVC horizontal } \\
\text { pipe }\left(\mathrm{p}_{2}\right)\end{array}$ & $\begin{array}{l}\text { Length }: 12 \mathrm{~m} \\
\text { Inner diameter }: 16.2 \mathrm{~cm} \\
\text { Thickens }: 3 \mathrm{~mm}\end{array}$ & $\begin{array}{l}\text { An outer pipe to enfold the } \\
\text { inner main one P1 and forms } \\
\text { an annular cross section space } \\
\text { to be filled with water. It is } \\
\text { considered as a suggested } \\
\text { addition to ETHE to be } \\
\text { investigated. }\end{array}$ \\
\hline $\begin{array}{l}\text { Four vertical PVC } \\
\text { pipes }\end{array}$ & Diameter $: 10.85 \mathrm{~cm}$ & $\begin{array}{l}\text { Two pipes connected to each } \\
\text { horizontal pipe on the ground } \\
\text { surface. One as the air inlet and } \\
\text { the other as the air outlet. }\end{array}$ \\
\hline $\begin{array}{l}\text { a transverse horizontal } \\
\text { pipe on the ground } \\
\text { surface }\end{array}$ & $\begin{array}{ll}\text { Length } & : 5 \mathrm{~m} \\
\text { Diameter } & : 10.85 \mathrm{~cm}\end{array}$ & $\begin{array}{l}\text { Works as air distributor to both } \\
\text { the two buried horizontal pipes } \\
\text { ( P1 ) }\end{array}$ \\
\hline Blower & $\begin{array}{l}3.2 \mathrm{~A}, 220 \mathrm{~V}, 0.75 \mathrm{~kW}, 50 \\
\mathrm{~Hz}, 2850 \mathrm{rpm}, \cos \theta=0.82 .\end{array}$ & $\begin{array}{l}\text { Blows the ambient air to pass } \\
\text { through the buried pipes (P1). }\end{array}$ \\
\hline Two air valves & Diameter : 4 inch & $\begin{array}{l}\text { Control the air flow rate for } \\
\text { both systems. }\end{array}$ \\
\hline Timer & $\begin{array}{l}24 \text { Hours Time Switch } \\
\text { HWD-G27 } \\
220-240 \mathrm{~V}, 50 \mathrm{~Hz}\end{array}$ & $\begin{array}{l}\text { Switches on/off the blower } \\
\text { according to the experimental } \\
\text { procedure regarding operation } \\
\text { duration. }\end{array}$ \\
\hline
\end{tabular}




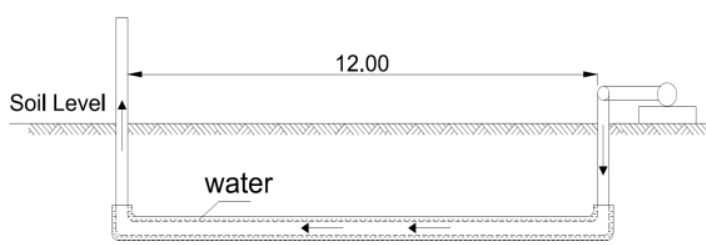

Front ( vertical ) view

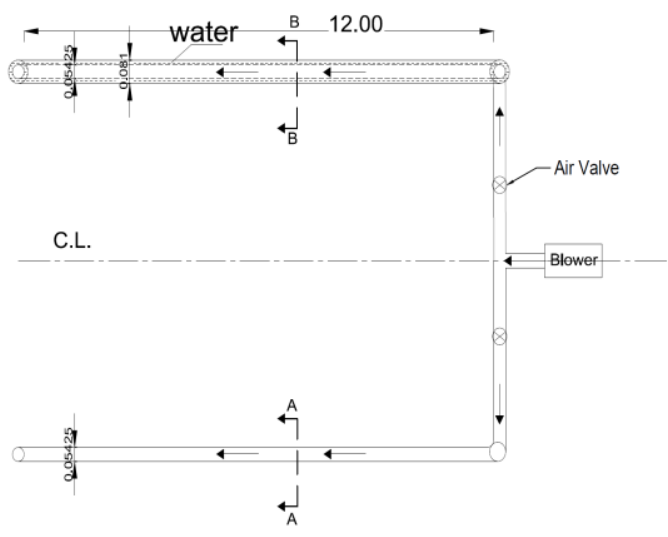

Top ( Plan ) view
Side view

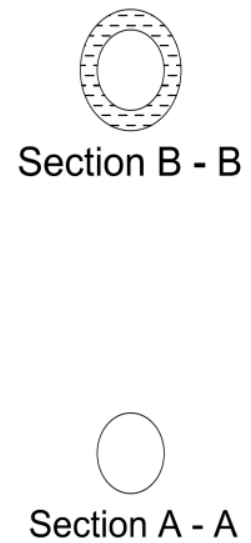

Section A - A

Figure 3: A schematic drawing for the whole experimental system.

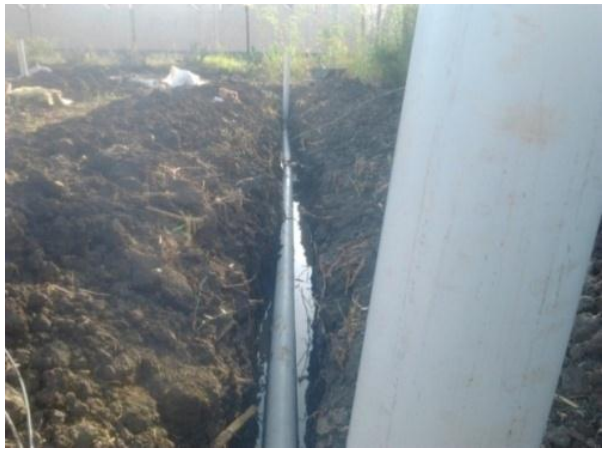

Figure 1: Burying of a pipe within the ditch

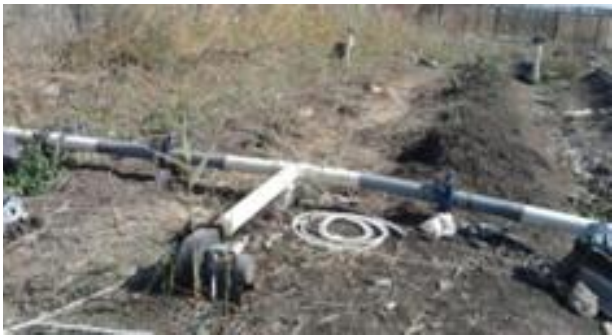

Figure 2: A photograph of the transverse horizontal pipe on the ground surface. 


\section{Methods :}

To judge the suggested ETHE the thermal energy rate removed or added from or to the air was calculated. Coefficient of performance (COP) was calculated as well.

\section{Thermal energy removed or added from or to air $\left(Q_{a i r}\right)$}

According to many researchers ( Pfafferott , 2003 ; Badescu , 2007; Darkwa et al., 2011 ; Mongkon et al., 2013 ) the rate of thermal energy removed from or added to air in watts $\left(Q_{\text {air }}\right)$ was calculated as follows:

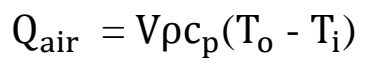

Where: $\mathrm{V}$ is the volumetric flow rate of air $\left(\mathrm{m}^{3} / \mathrm{s}\right), \rho$ is the density of air $\left(\mathrm{kg} / \mathrm{m}^{3}\right), \mathrm{c}_{\mathrm{p}}$ is the specific heat of air $\left(1007 \mathrm{~J} /\left(\mathrm{Kg} \cdot{ }^{\circ} \mathrm{C}\right)\right), \mathrm{T}_{\mathrm{i}}$ and $\mathrm{T}_{\mathrm{o}}$ are the inlet and outlet air temperature $\left({ }^{\circ} \mathrm{C}\right)$ respectively.

\section{Coefficient of performance (COP)}

According to many researchers ( Ozgener and Ozgener, 2010 a,b ; Ozgener et al., 2011 ; Mongkon et al., 2013 ) the Coefficient of performance (COP) of the system was determined as follows:

$$
\mathrm{COP}=\mathrm{Q}_{\mathrm{air}} / \mathrm{W}_{\mathrm{b}}
$$

in which:

$$
\mathrm{W}_{\mathrm{b}}=\mathrm{I} \mathrm{V}_{\text {ele }} \cos \theta
$$

Where $\mathrm{W}_{\mathrm{b}}$ is the work input (consumption) rate to the blower (W), I is the input electrical current (A), $\mathrm{V}_{\text {ele }}$ is the voltage of the input electrical current $(220 \mathrm{~V})$ and $\cos \theta$ is the power factor $(0.82)$.

\section{Experimental procedure}

The experimental system was accomplished and checked. Five air velocities $(1.8,3.7,5.7,7.7$ and $9.7 \mathrm{~m} / \mathrm{s})$ were determined by the aid of the blower gate which enables changing the area through which the ambient air entering the blower and consequently the air flow rate in terms of air velocity. Four operating durations ( 6, 9, 12 and 22 hours) were investigated. However the last operating duration (22 hours) was suggested lately to get a more chance of duration for the second system (S2) expected action to arise. The main experiments were run at each operating duration for all air velocities.

\section{RUSULTS AND DISCUSSION}

The following results show the thermal potential of the investigated ETHE systems in cooling and heating modes. However temperature 
reduction / rise, general effect of air velocity, thermal energy rate released / added, COP and the general trend between the inlet air temperatures and outlet air temperatures were illustrated. The hourly thermal performance was shown at the middle value of air velocity namely $5.7 \mathrm{~m} / \mathrm{s}$ for all operating durations since the general trend for all air velocities is almost the same.

\section{Cooling mode}

\section{Performance throughout different operating durations}

Figure 4 shows hourly variation in inlet, outlet and ambient air temperatures for both systems S1 and S2 in cooling mode for different operating durations at air velocity $5.7 \mathrm{~m} / \mathrm{s}$. Generally a cooling potential was obviously achieved. There was a heating effect at the end of some days for 9, 12 hours and 22 hours operating durations because of the inlet air temperatures were lower than soil temperature. While when the system operated for 6 hours during which higher values of ambient air temperatures were existed. This leads to big differences between the inlet air temperatures and soil temperature and in turn it was not allowed to heating effect to be arised. When the systems operate for 22 hours, almost all day, a dual effect was found. Therefore the values of air temperature during any heating process (mode) were excluded from the text and calculations in following section to maintain cooling mode discussion. For all operating durations the inlet air temperatures for both systems S1 and S2 take the same trend of ambient air temperatures but differ in their small range. The outlet temperatures for S1 were lower than that for S2 in all days and they were varied in a narrow range which may led to good level of temperature control that could be achieved by the both systems. Table 2 shows temperature averages throughout each operating duration for both systems $\mathrm{S} 1$ and $\mathrm{S} 2$ at air velocity $5.7 \mathrm{~m} / \mathrm{s}$. Figure 5 shows the average of inlet and outlet air temperatures as effected by air velocity at different operating durations for both systems S1 and S2 during cooling mode. It was appreciable that when the air velocity (i.e. air flow rate) increases the average of outlet air temperatures increase (less cooling) because of the air contact time with the heat sink (soil) decreases when the air velocity increase. 

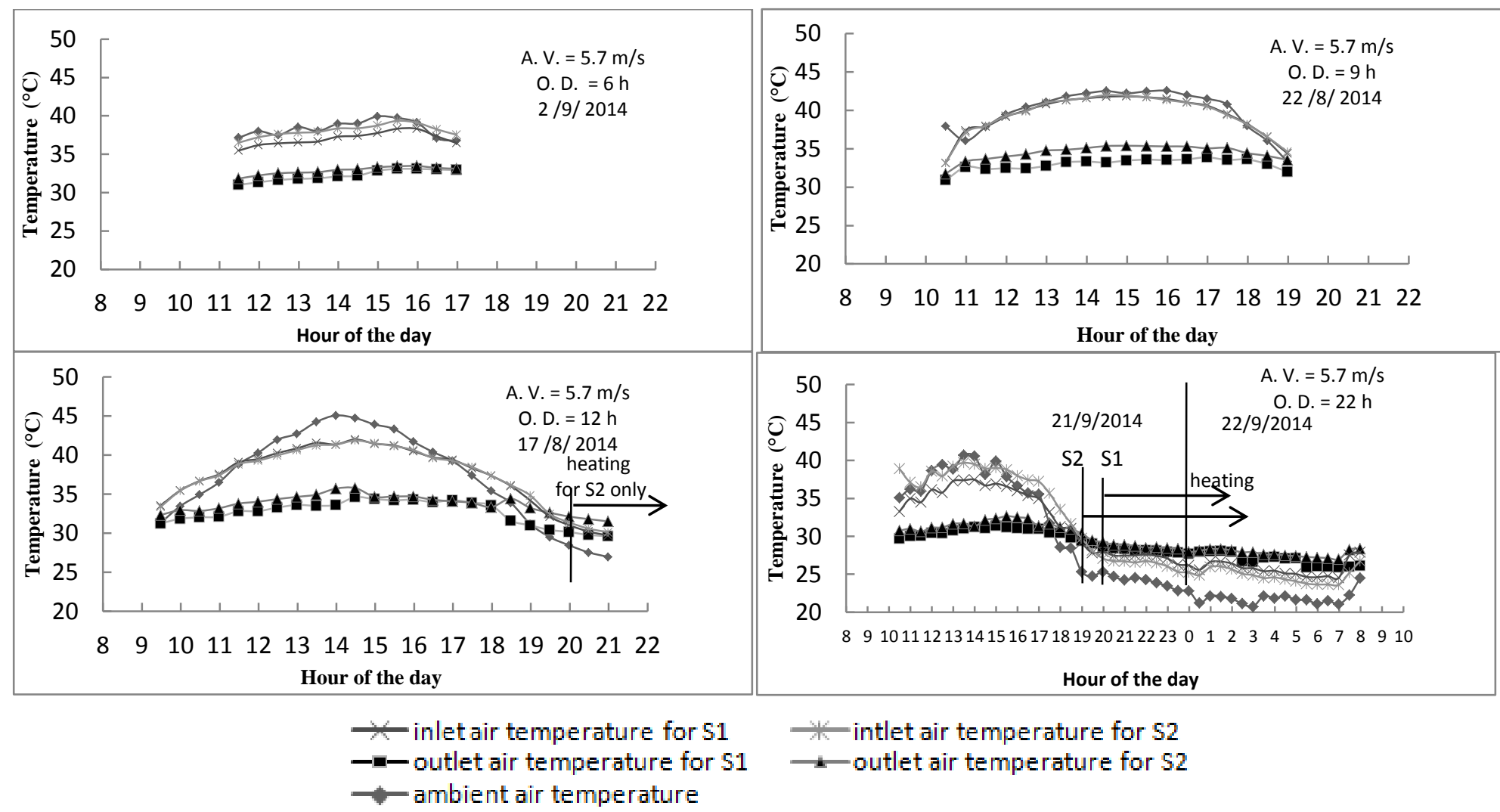

Figure 4 : Hourly variation in inlet, outlet and ambient air temperatures for both systems S1 and S2 in cooling mode for different operating durations (O. D.) at air velocity (A. V.) $5.7 \mathrm{~m} / \mathrm{s}$. 
Table 2 :Temperature averages throughout each operating duration for both systems $\mathrm{S} 1$ and $\mathrm{S} 2$ at air velocity $5.7 \mathrm{~m} / \mathrm{s}$.

\begin{tabular}{|c|c|c|c|c|}
\hline $\begin{array}{c}\text { Operating } \\
\text { duration }\end{array}$ & $\begin{array}{c}\text { The average of } \\
\text { ambient air } \\
\text { temperatures }\end{array}$ & $\begin{array}{c}\text { The mean of the } \\
\text { average inlet air } \\
\text { temperatures for } \\
\mathrm{S} 1 \text { and } \mathrm{S} 2\end{array}$ & $\begin{array}{c}\text { The average of } \\
\text { outlet air } \\
\text { temperatures } \\
\text { for S1 }\end{array}$ & $\begin{array}{c}\text { The average } \\
\text { of outlet air } \\
\text { temperatures } \\
\text { for S2 }\end{array}$ \\
\hline 6 & $\begin{array}{c}38.31{ }^{\circ} \mathrm{C} \\
(\mathrm{SD}=1.06)\end{array}$ & $\begin{array}{c}37.53{ }^{\circ} \mathrm{C} \\
(\mathrm{SD}=0.84)\end{array}$ & $\begin{array}{c}32.24{ }^{\circ} \mathrm{C} \\
(\mathrm{SD}=0.73)\end{array}$ & $\begin{array}{c}32.86{ }^{\circ} \mathrm{C} \\
(\mathrm{SD}=0.5)\end{array}$ \\
\hline 9 & $\begin{array}{c}39.58^{\circ} \mathrm{C} \\
(\mathrm{SD}=2.76)\end{array}$ & $\begin{array}{c}39.36^{\circ} \mathrm{C} \\
(\mathrm{SD}=2.62)\end{array}$ & $\begin{array}{c}32.97{ }^{\circ} \mathrm{C} \\
(\mathrm{SD}=0.74)\end{array}$ & $\begin{array}{c}34.48^{\circ} \mathrm{C}(\mathrm{SD} \\
=0.96)\end{array}$ \\
\hline \multirow{2}{*}{12} & $\begin{array}{c}36.94^{\circ} \mathrm{C} \\
(\mathrm{SD}=5.89)\end{array}$ & $\begin{array}{c}38.11^{\circ} \mathrm{C} \\
(\mathrm{SD}=3.17)\end{array}$ & $\begin{array}{c}32.61{ }^{\circ} \mathrm{C} \\
(\mathrm{SD}=1.58)\end{array}$ & $\begin{array}{c}34.09^{\circ} \mathrm{C}(\mathrm{SD} \\
=0.91)\end{array}$ \\
\hline 22 & $\begin{array}{c}34.99{ }^{\circ} \mathrm{C} \\
(\mathrm{SD}=5.41)\end{array}$ & $\begin{array}{c}35.96{ }^{\circ} \mathrm{C} \\
(\mathrm{SD}=2.59)\end{array}$ & $\begin{array}{c}30.16^{\circ} \mathrm{C} \\
(\mathrm{SD}=1.53)\end{array}$ & $\begin{array}{c}31.55{ }^{\circ} \mathrm{C}(\mathrm{SD} \\
=0.63)\end{array}$ \\
\hline
\end{tabular}

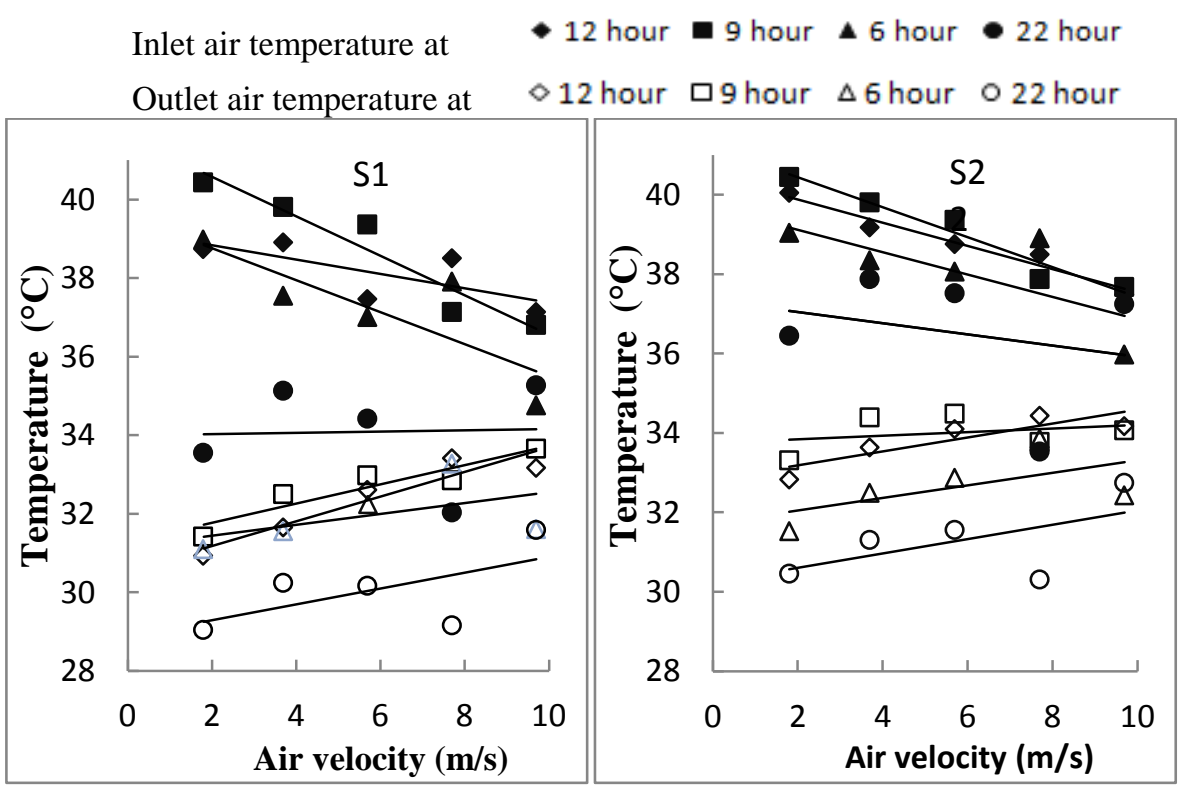

Figure 5 : The average of outlet air temperatures as effected by air velocities (i.e. air flow rate) and the corresponding inlet air temperature at different operating durations for both systems S1 and S2 during cooling mode.

Regarding relative humidity, for operating durations 6, 9 and 12 hours it was found that the outlet relative humidity for both systems was higher than the inlet one since it was a sensible cooling process regarding psychrometrics. During operating duration 22 hours it is clear that the 
outlet relative humidity for both systems was higher than the inlet one during daytime and lower than it during nighttime because of the well known opposite relationship between temperature and relative humidity.

\section{Cooling potential in terms of temperature reduction}

Temperature reduction was indicated only for system $\mathrm{S} 1$ since it varies from S2 in less than $2{ }^{\circ} \mathrm{C}$. However, Figure 6 shows hourly variation in temperature reduction for $\mathrm{S} 1$ at different operating durations and air velocities. For all treatments the temperature reduction behaves the same trend as the inlet air temperatures. Because of the inlet air temperatures varied in high amplitude and the outlet air temperatures varied in small ones, the values of temperature reduction have maximum and minimum values at the maximum and minimum values respectively of the inlet air temperature. Also it was evident from the general trend that the temperature reduction decreases when air velocity (i.e. mass flow rate) increases. This is due to the air contact time to the heat sink was shorter when air velocity increases which causes less heat transfer or loss form air and finally low temperature reduction.

\section{Cooling potential in terms of thermal energy rate removed and COP}

Table 3 shows maximum, minimum and the average of thermal energy rate removed from air and COP for both systems S1 and S2 in cooling mode. Thermal energy rate removed has the same trend as temperature reduction. This is due to that the only varied factor influence the thermal energy rate removed is the temperature reduction since the air flow rate and $c_{p}$ were fixed at each air velocity and the air density had a very small variation with air temperature. Regarding the operating duration of 22 hours and at the end of the operating durations of 9 and 12 hours there were some transfer to a heating effect as mentioned before. These values of energy gain were excluded here to keep the investigation of cooling potential. It is clear that the thermal energy rate removed for S1 was almost equal to S2 at operating duration 6 hours. But the system S1 has thermal energy rate removed higher than the system S2 at operating durations 9 and 12 hours. 

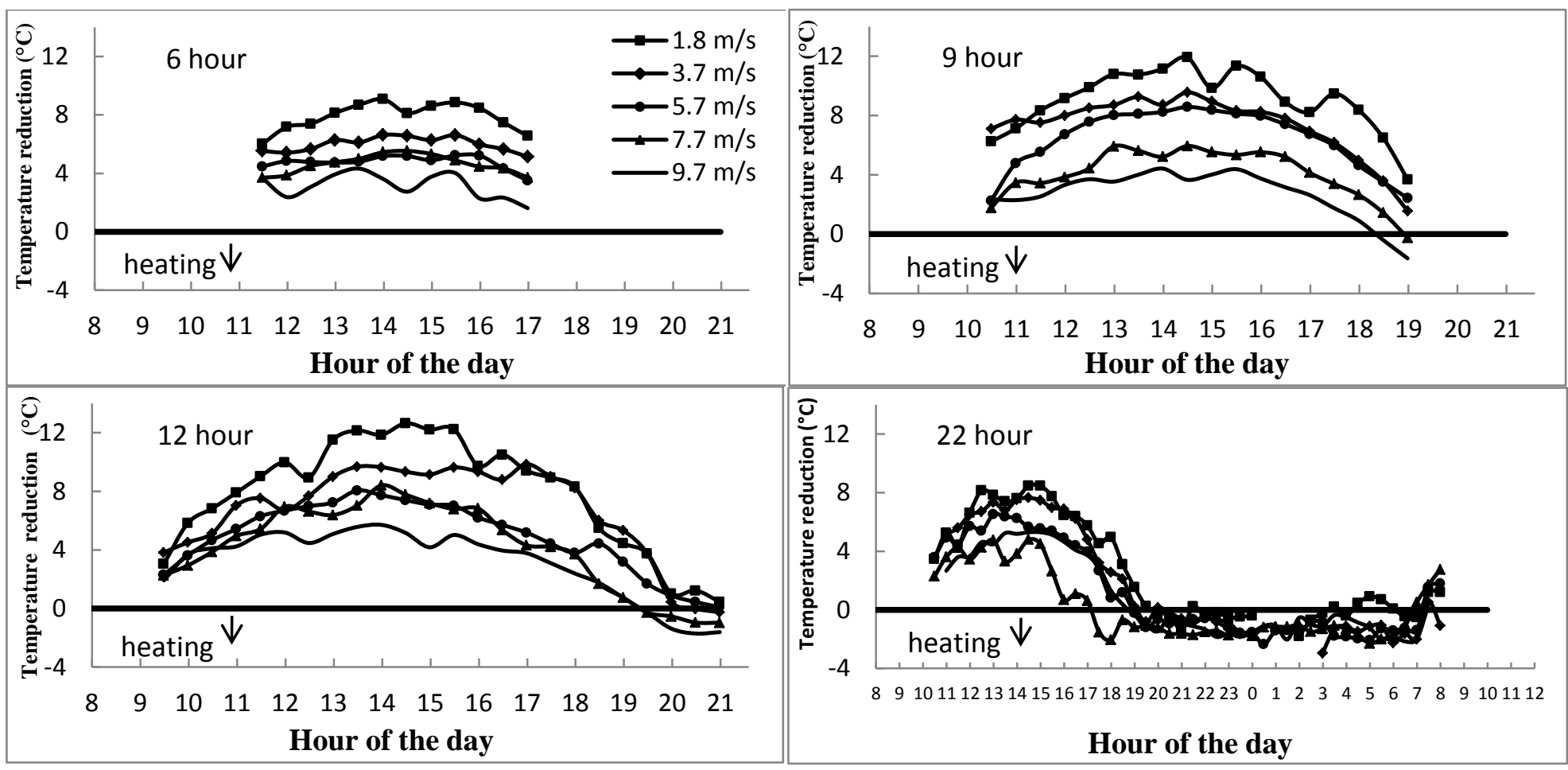

Figure 6 : Hourly variation in temperature reduction for system S1 in cooling mode at different operating durations and air velocities. 
Table 3 : The maximum, minimum and the average of thermal energy rate removed from air and COP for both systems (S1 and S2) in cooling mode.

\begin{tabular}{|c|c|c|c|c|c|c|c|c|c|c|c|c|c|}
\hline \multirow{3}{*}{$\begin{array}{l}\text { A. } v \text {. } \\
\mathrm{m} / \mathrm{s}\end{array}$} & \multirow{3}{*}{$\begin{array}{c}\text { O.D. } \\
\text { h. }\end{array}$} & \multicolumn{6}{|c|}{ Thermal energy rate removed $(\mathrm{kW})$} & \multicolumn{6}{|c|}{ Coefficient of performance } \\
\hline & & \multicolumn{3}{|c|}{$\mathrm{S} 1$} & \multicolumn{3}{|c|}{$\mathrm{S} 2$} & \multicolumn{3}{|c|}{$\mathrm{S} 1$} & \multicolumn{3}{|c|}{$\mathrm{S} 2$} \\
\hline & & Max. & Min. & Ave. & Max. & Min. & Ave. & Max. & Min. & Ave. & Max. & Min. & Ave. \\
\hline 1.8 & 6 & 1.706 & 1.146 & 1.486 & 1.549 & 1.116 & 1.417 & 1.11 & 0.75 & 0.97 & 1.01 & 0.73 & 0.92 \\
\hline 3.7 & 6 & 2.578 & 2.005 & 2.332 & 2.589 & 1.825 & 2.278 & 1.63 & 1.27 & 1.48 & 1.64 & 1.16 & 1.44 \\
\hline 5.7 & 6 & 3.138 & 2.116 & 2.865 & 3.546 & 2.664 & 3.122 & 1.93 & 1.3 & 1.76 & 2.18 & 1.64 & 1.92 \\
\hline 7.7 & 6 & 4.468 & 3.01 & 3.748 & 4.976 & 3.136 & 4.084 & 2.68 & 1.8 & 2.25 & 2.98 & 1.88 & 2.45 \\
\hline 9.7 & 6 & 4.441 & 1.678 & 3.244 & 4.579 & 2.341 & 3.653 & 2.59 & 0.98 & 1.89 & 2.67 & 1.37 & 2.13 \\
\hline 1.8 & 9 & 2.212 & 0.705 & 1.689 & 1.839 & 0.335 & 1.335 & 1.44 & 0.46 & 1.1 & 1.2 & 0.22 & 0.87 \\
\hline 3.7 & 9 & 3.658 & 0.614 & 2.822 & 2.785 & 0.291 & 2.092 & 2.32 & 0.39 & 1.79 & 1.76 & 0.18 & 1.33 \\
\hline 5.7 & 9 & 5.239 & 1.374 & 3.899 & 4.049 & 0.641 & 2.98 & 3.23 & 0.85 & 2.4 & 2.49 & 0.39 & 1.84 \\
\hline 7.7 & 9 & 4.791 & 1.18 & 3.47 & 4.508 & 0.207 & 3.32 & 2.87 & 0.71 & 2.08 & 2.7 & 0.12 & 1.99 \\
\hline 9.7 & 9 & 4.505 & 0.939 & 3.219 & 6.035 & 0.083 & 3.685 & 2.63 & 0.55 & 1.88 & 3.52 & 0.05 & 2.15 \\
\hline 1.8 & 12 & 2.355 & 0.087 & 1.465 & 1.789 & 0.571 & 1.353 & 1.54 & 0.06 & 0.96 & 1.17 & 0.37 & 0.88 \\
\hline 3.7 & 12 & 3.793 & 0.183 & 2.805 & 3.006 & 0.237 & 2.135 & 2.4 & 0.12 & 1.78 & 1.9 & 0.15 & 1.35 \\
\hline 5.7 & 12 & 4.766 & 0.055 & 2.899 & 4.064 & 0.637 & 2.776 & 2.94 & 0.03 & 1.79 & 2.5 & 0.39 & 1.71 \\
\hline 7.7 & 12 & 6.718 & 0.617 & 4.105 & 4.937 & 0.625 & 3.272 & 4.03 & 0.37 & 2.46 & 2.96 & 0.37 & 1.96 \\
\hline 9.7 & 12 & 5.783 & 0.766 & 4.055 & 4.877 & 1.156 & 3.381 & 3.37 & 0.45 & 2.37 & 2.85 & 0.67 & 1.97 \\
\hline 1.8 & 22 & 1.6 & 0.016 & 0.86 & 1.959 & 0.062 & 1.205 & 1.04 & 0.01 & 0.56 & 1.28 & 0.04 & 0.79 \\
\hline 3.7 & 22 & 2.961 & 0.052 & 1.908 & 4.23 & 0.164 & 2.563 & 1.88 & 0.03 & 1.21 & 2.68 & 0.1 & 1.62 \\
\hline 5.7 & 22 & 3.911 & 0.496 & 2.573 & 4.954 & 0.441 & 3.597 & 2.41 & 0.31 & 1.59 & 3.05 & 0.27 & 2.22 \\
\hline 7.7 & 22 & 3.912 & 0.429 & 2.369 & 4.68 & 0.042 & 2.643 & 2.34 & 0.26 & 1.42 & 2.8 & 0.03 & 1.58 \\
\hline 9.7 & 22 & 5.402 & 0.386 & 3.771 & 6.799 & 0.188 & 4.613 & 3.15 & 0.23 & 2.2 & 3.97 & 0.11 & 2.69 \\
\hline
\end{tabular}

This is due to the temperature reduction for S1 was higher than S2. However, at operating duration 22 hours the thermal energy rate removed for $\mathrm{S} 2$ was higher than $\mathrm{S} 1$ due to the temperature reduction for $\mathrm{S} 2$ was higher than S1.In addition, results may point to that the action of S2 in extending the duration of air tempering was not clear. General trend indicates that the thermal energy rate removed increased by increasing air 
velocity (air flow rate) although the temperature reduction decreases. This is because of the effect of increasing of air flow rate was predominant than the effect of temperature reduction. Regarding COP it is pronounced that $\mathrm{COP}$ takes the same trend of thermal energy rate removed where the COP calculations depended on electricity consumed and thermal energy rate removed. The first changes in a very small range for all days while the second changes sharply every hour.

\section{Heating Mode}

\section{Performance throughout different operating durations}

Figure 7 shows hourly variation in inlet, outlet and ambient air temperatures for both systems S1 and S2 for different operating durations at air velocity $5.7 \mathrm{~m} / \mathrm{s}$. During operating durations 6, 9 and 12 hours the ambient air temperatures change in small range. Also the inlet air temperatures for both systems change in small range but the inlet air temperatures exceed than the ambient one at an average of $3.29{ }^{\circ} \mathrm{C}$ because of the blower action. But for operating duration of 22 hours it was clear that both systems work positively in heating air during almost day hours except for hours around 7:00 to 17:00 in which a reverse process (cooling) appeared. However the values of air temperature during this undesired cooling mode were excluded from the text and from the calculations in following section to maintain heating mode discussion.

The inlet air temperatures for both systems differ from ambient air temperatures in small range during day time but the range becomes large during night because the blower act to increase the ambient air temperatures at an average of $2.77^{\circ} \mathrm{C}$ before entering the systems. The outlet air temperatures for $\mathrm{S} 1$ were almost equal to that for $\mathrm{S} 2$ in all days. The outlet air temperatures for both systems were varied in a narrow range which may point to a good level of temperature control that could be achieved by both systems. Figure 8 shows the average of inlet and outlet air temperatures as effected by air velocity at different operating durations for both systems S1 and S2 during heating mode. When air velocity increases the average of outlet air temperatures decrease (less heating) because of the air contact time with the heat source decreases. 


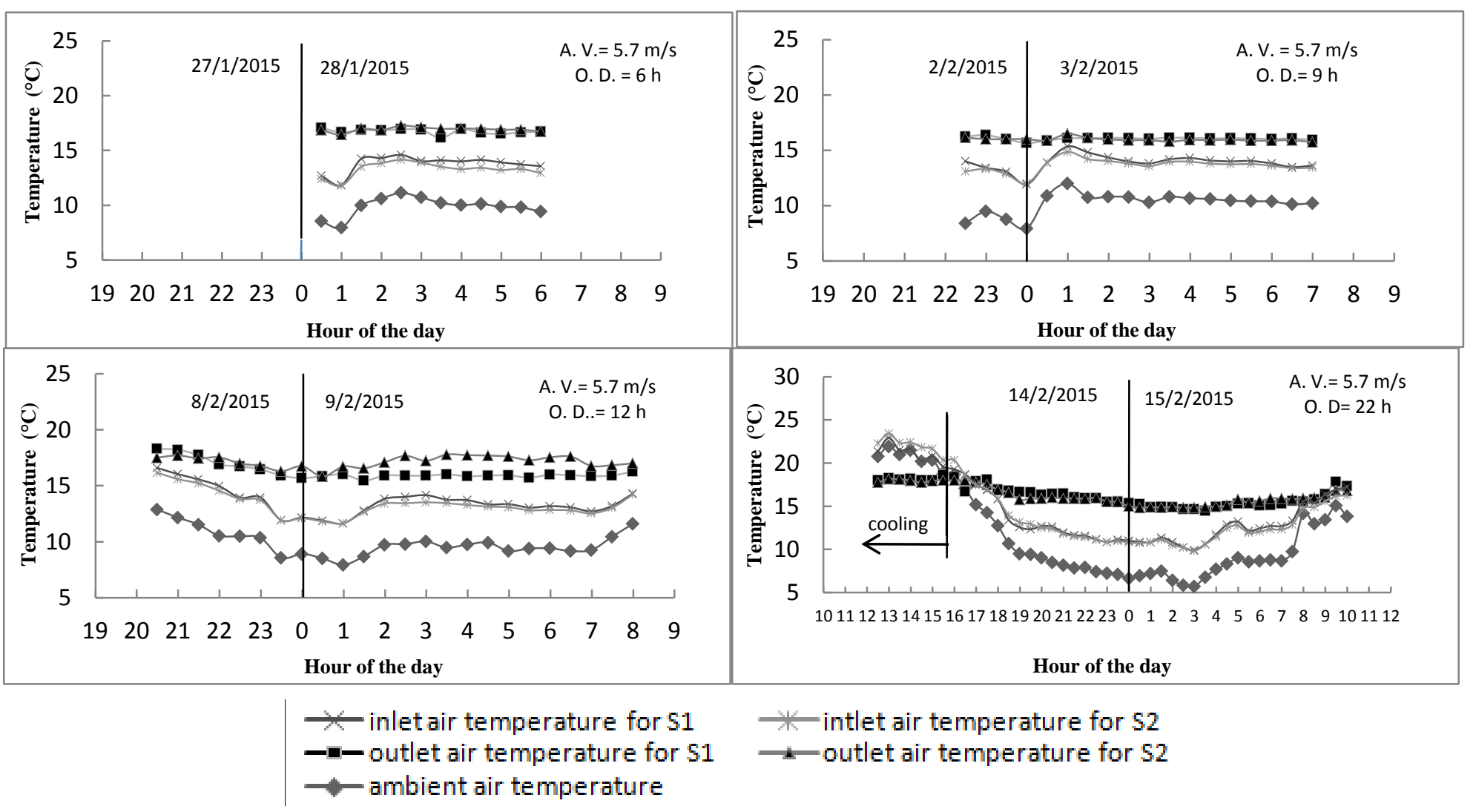

Figure 7 : Hourly variation in inlet, outlet and ambient air temperatures for both systems S1 and S2 in heating mode for different operating durations (O. D.) at air velocity (A.V.) $5.7 \mathrm{~m} / \mathrm{s}$. 


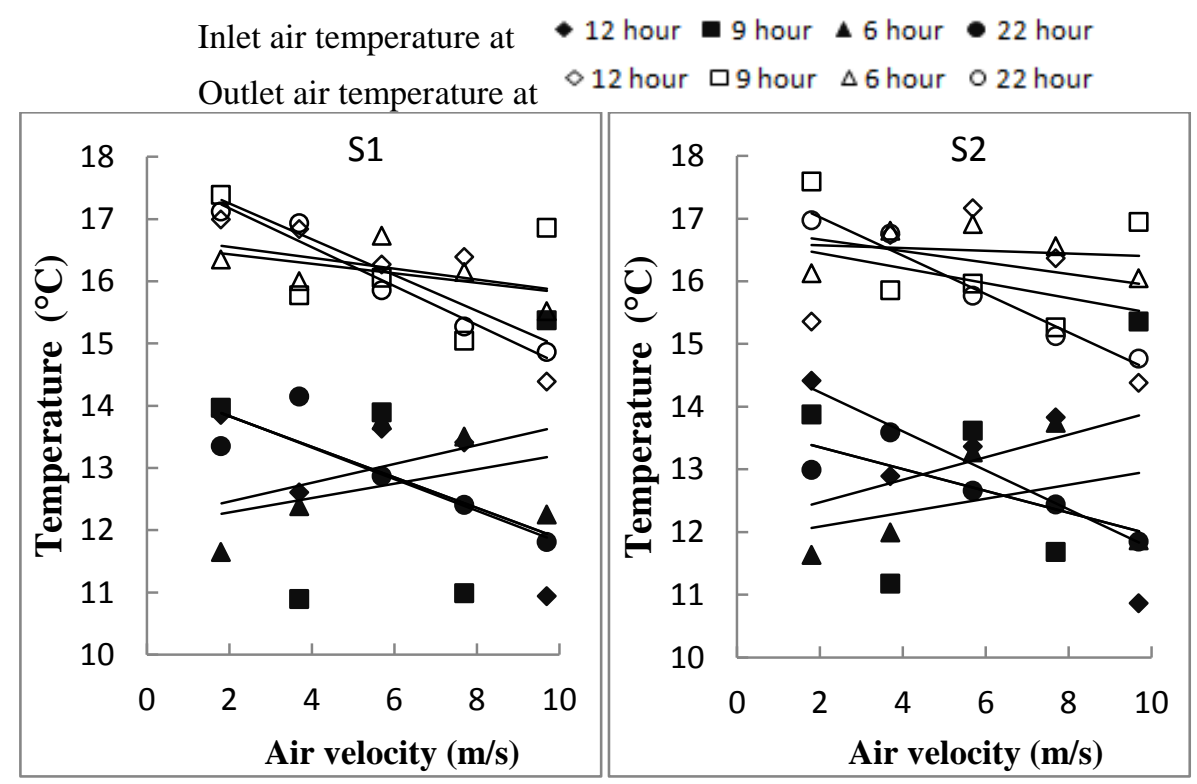

Figure 8: The average of outlet air temperatures as effected by air velocities (i.e. air flow rate) and the corresponding inlet air temperature at different operating durations for both systems S1 and S2 during heating mode.

Table 4 : Temperature averages throughout each operating duration for both systems $\mathrm{S} 1$ and $\mathrm{S} 2$ at air velocity $5.7 \mathrm{~m} / \mathrm{s}$.

\begin{tabular}{|c|c|c|c|c|}
\hline $\begin{array}{c}\text { Operating } \\
\text { duration }\end{array}$ & $\begin{array}{c}\text { The average } \\
\text { of ambient } \\
\text { air } \\
\text { temperatures }\end{array}$ & $\begin{array}{c}\text { The mean of } \\
\text { the average } \\
\text { inlet air } \\
\text { temperatures } \\
\text { for } \mathrm{S} 1 \text { and } \mathrm{S} 2\end{array}$ & $\begin{array}{c}\text { The average } \\
\text { of outlet air } \\
\text { temperatures } \\
\text { for } \mathrm{S} 1\end{array}$ & $\begin{array}{c}\text { The } \\
\text { average of } \\
\text { outlet air } \\
\text { temperatur } \\
\text { es for } \mathrm{S} 2\end{array}$ \\
\hline 6 & $\begin{array}{c}9.86^{\circ} \mathrm{C} \\
(\mathrm{SD}=0.89)\end{array}$ & $\begin{array}{c}13.52^{\circ} \mathrm{C} \\
(\mathrm{SD}=0.71)\end{array}$ & $\begin{array}{c}16.73^{\circ} \mathrm{C} \\
(\mathrm{SD}=0.24)\end{array}$ & $\begin{array}{c}16.91^{\circ} \mathrm{C} \\
(\mathrm{SD}=0.2)\end{array}$ \\
\hline 9 & $\begin{array}{c}10^{\circ} \mathrm{C} \\
(\mathrm{SD}=0.99)\end{array}$ & $\begin{array}{c}13.75^{\circ} \mathrm{C} \\
(\mathrm{SD}=0.66)\end{array}$ & $\begin{array}{c}16.05^{\circ} \mathrm{C} \\
(\mathrm{SD}=0.14)\end{array}$ & $\begin{array}{c}15.96^{\circ} \mathrm{C} \\
(\mathrm{SD}=0.16)\end{array}$ \\
\hline 12 & $\begin{array}{c}9.9^{\circ} \mathrm{C} \\
(\mathrm{SD}=1.19) .\end{array}$ & $\begin{array}{c}13.49^{\circ} \mathrm{C} \\
(\mathrm{SD}=1.19)\end{array}$ & $\begin{array}{c}16.27^{\circ} \mathrm{C} \\
(\mathrm{SD}=0.77) .\end{array}$ & $\begin{array}{c}17.16^{\circ} \mathrm{C} \\
(\mathrm{SD}=0.52) .\end{array}$ \\
\hline 22 & $\begin{array}{c}9.33^{\circ} \mathrm{C} \\
(\mathrm{SD}=2.79)\end{array}$ & $\begin{array}{c}12.76^{\circ} \mathrm{C} \\
(\mathrm{SD}=2.14)\end{array}$ & $\begin{array}{c}15.85^{\circ} \mathrm{C} \\
(\mathrm{SD}=0.97)\end{array}$ & $\begin{array}{c}15.77^{\circ} \mathrm{C} \\
(\mathrm{SD}=0.75)\end{array}$ \\
\hline
\end{tabular}

Table 4 shows the temperature averages throughout each operating duration for both systems S1 and S2 at air velocity $5.7 \mathrm{~m} / \mathrm{s}$. Regarding the outlet relative humidity it was revealed in some days that it was 
higher than the inlet one as it was not expected. This may be caused by some water evaporation occurs during the air pass through the pipes. This water may reached the pipes as rain drops or condensed water during early morning.

\section{Heating potential in terms of temperature rise}

Because of the hourly temperature rise for both systems S1 and S2 was revealed to be close to each other it was shown only for $\mathrm{S} 1$ as illustrated in Figure 9. As a general trend the temperature rise tend to decrease by increasing air velocity because of the shorten in the air contact time with the heat source as mentioned before. However only one exception for S2 at operating duration 12 hours in which temperature rise increases by increasing air velocity and this is considered disagreement with the known phenomena and probably due to some measurements difficulties. The maximum temperature rise of about $6.27{ }^{\circ} \mathrm{C}$ was found for $\mathrm{S} 1$ at 3.7 $\mathrm{m} / \mathrm{s}$ and operating duration of 12 hours.

\section{Heating potential in terms of thermal energy rate added and COP}

Table 5 shows maximum, minimum and average of thermal energy rate added to air and COP for both systems S1 and S2 in heating mode for all treatments. Obviously the thermal energy rate added behaves the same trend as the temperature rise. It is clear that the thermal energy rate add to air by S1 was almost equal to that for S2. Regarding the operating duration of 22 hours there were some transformation to energy rate removed (cooling effect) as mentioned before. These values of energy removed were excluded here to keep the investigation of heating potential. General trend of the thermal energy rate added increased by increasing air velocity (air flow rate) although the temperature rise decreases. This is because of the effect of increasing of air flow rate was predominant than the effect of the temperature rise. Also it is pronounced from Table 5 the COP takes the same trend of the thermal energy rate added as in cooling mode.

\section{The relationship between the inlet and outlet air temperatures}

Figures 10 shows the relationship between inlet and outlet air temperatures for both systems S1 and S2 in cooling and heating modes at various air velocities for all operating durations. Values above the equality line denote heating and below it denote cooling. 


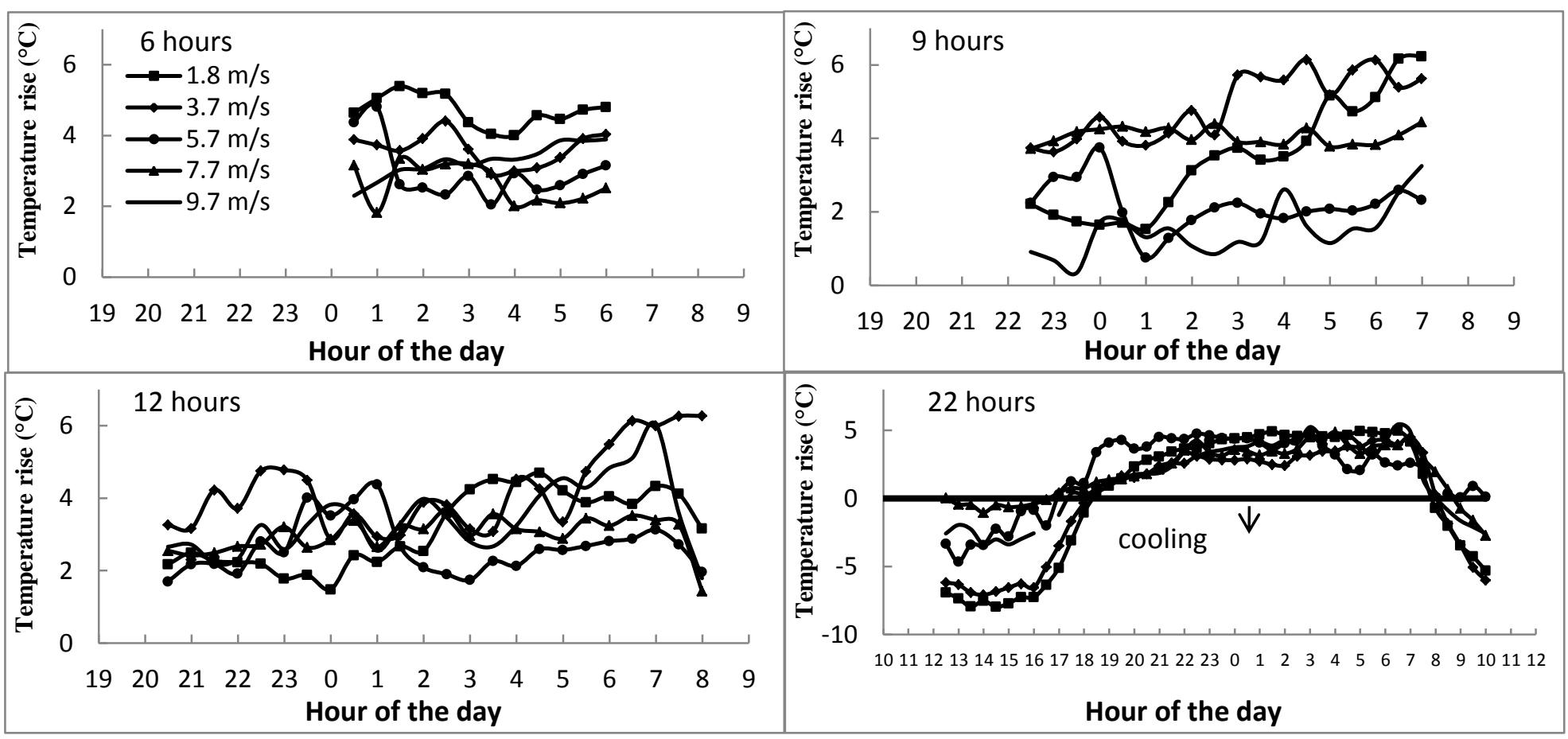

Figure 9 :Hourly variation in temperature rise for system S1 in heating mode at different operating durations and air velocities. 
Table 5 : Maximum, minimum and average of thermal energy rate added to air and COP for both systems S1 and S2 in heating mode.

\begin{tabular}{|c|c|c|c|c|c|c|c|c|c|c|c|c|c|}
\hline \multirow{3}{*}{$\begin{array}{l}\text { A. v. } \\
\mathrm{m} / \mathrm{s}\end{array}$} & \multirow{3}{*}{$\begin{array}{c}\text { O. D. } \\
\text { h. }\end{array}$} & \multicolumn{6}{|c|}{ Thermal energy rate added $(\mathrm{kW})$} & \multicolumn{6}{|c|}{ Coefficient of performance } \\
\hline & & \multicolumn{3}{|c|}{ S1 } & \multicolumn{3}{|c|}{ S2 } & \multicolumn{3}{|c|}{$\mathrm{S} 1$} & \multicolumn{3}{|c|}{$\mathrm{S} 2$} \\
\hline & & Max. & Min. & Ave. & Max. & Min. & Ave. & Max. & Min. & Ave. & Max. & Min. & Ave. \\
\hline 1.8 & 6 & 0.102 & 0.075 & 0.088 & 0.091 & 0.076 & 0.084 & 0.67 & 0.49 & 0.58 & 0.59 & 0.5 & 0.55 \\
\hline 3.7 & 6 & 0.17 & 0.111 & 0.14 & 0.214 & 0.161 & 0.186 & 1.08 & 0.71 & 0.88 & 1.36 & 1.02 & 1.18 \\
\hline 5.7 & 6 & 0.289 & 0.121 & 0.177 & 0.28 & 0.181 & 0.217 & 1.78 & 0.75 & 1.09 & 1.73 & 1.11 & 1.33 \\
\hline 7.7 & 6 & 0.271 & 0.148 & 0.212 & 0.26 & 0.179 & 0.226 & 1.63 & 0.89 & 1.27 & 1.56 & 1.07 & 1.35 \\
\hline 9.7 & 6 & 0.39 & 0.237 & 0.331 & 0.529 & 0.296 & 0.422 & 2.28 & 1.39 & 1.93 & 3.08 & 1.73 & 2.46 \\
\hline 1.8 & 9 & 0.117 & 0.029 & 0.064 & 0.114 & 0.032 & 0.07 & 0.76 & 0.19 & 0.42 & 0.75 & 0.21 & 0.45 \\
\hline 3.7 & 9 & 0.236 & 0.142 & 0.188 & 0.24 & 0.12 & 0.18 & 1.5 & 0.9 & 1.19 & 1.52 & 0.76 & 1.14 \\
\hline 5.7 & 9 & 0.224 & 0.044 & 0.129 & 0.239 & 0.097 & 0.14 & 1.38 & 0.27 & 0.79 & 1.47 & 0.6 & 0.86 \\
\hline 7.7 & 9 & 0.358 & 0.301 & 0.326 & 0.343 & 0.25 & 0.287 & 2.14 & 1.81 & 1.95 & 2.05 & 1.5 & 1.72 \\
\hline 9.7 & 9 & 0.33 & 0.035 & 0.15 & 0.273 & 0.081 & 0.161 & 1.92 & 0.2 & 0.88 & 1.59 & 0.47 & 0.94 \\
\hline 1.8 & 12 & 0.088 & 0.028 & 0.059 & 0.073 & 0.024 & 0.039 & 0.58 & 0.18 & 0.39 & 0.47 & 0.16 & 0.26 \\
\hline 3.7 & 12 & 0.25 & 0.11 & 0.165 & 0.231 & 0.086 & 0.149 & 1.58 & 0.7 & 1.04 & 1.46 & 0.55 & 0.95 \\
\hline 5.7 & 12 & 0.258 & 0.103 & 0.157 & 0.299 & 0.082 & 0.227 & 1.59 & 0.63 & 0.97 & 1.74 & 0.48 & 1.32 \\
\hline 7.7 & 12 & 0.293 & 0.119 & 0.241 & 0.257 & 0.101 & 0.205 & 1.75 & 0.71 & 1.44 & 1.54 & 0.61 & 1.23 \\
\hline 9.7 & 12 & 0.63 & 0.187 & 0.351 & 0.534 & 0.173 & 0.357 & 3.67 & 1.09 & 2.05 & 3.11 & 1.01 & 2.08 \\
\hline 1.8 & 22 & 0.102 & 0.006 & 0.077 & 0.111 & 0.001 & 0.082 & 0.67 & 0.04 & 0.51 & 0.73 & 0.01 & 0.54 \\
\hline 3.7 & 22 & 0.192 & 0.011 & 0.117 & 0.194 & 0.043 & 0.134 & 1.22 & 0.07 & 0.74 & 1.23 & 0.27 & 0.85 \\
\hline 5.7 & 22 & 0.312 & 0.005 & 0.201 & 0.33 & 0.022 & 0.204 & 1.92 & 0.03 & 1.24 & 2.03 & 0.14 & 1.25 \\
\hline 7.7 & 22 & 0.435 & 0.036 & 0.253 & 0.411 & 0.052 & 0.237 & 2.61 & 0.22 & 1.52 & 2.46 & 0.31 & 1.42 \\
\hline 9.7 & 22 & 0.614 & 0.009 & 0.341 & 0.574 & 0.03 & 0.325 & 3.58 & 0.05 & 1.99 & 3.35 & 0.17 & 1.9 \\
\hline
\end{tabular}

A moderate direct relationship between inlet and outlet air temperatures was revealed in both cases. The difference in slopes of the general trend line of the studied treatments and the equality line emphasizes the cooling and heating action of both systems although some opposite actions related to some operating durations were existed. During cooling mode an undesired heating effect occurred at operating durations of 9,12 and 22 hours. 

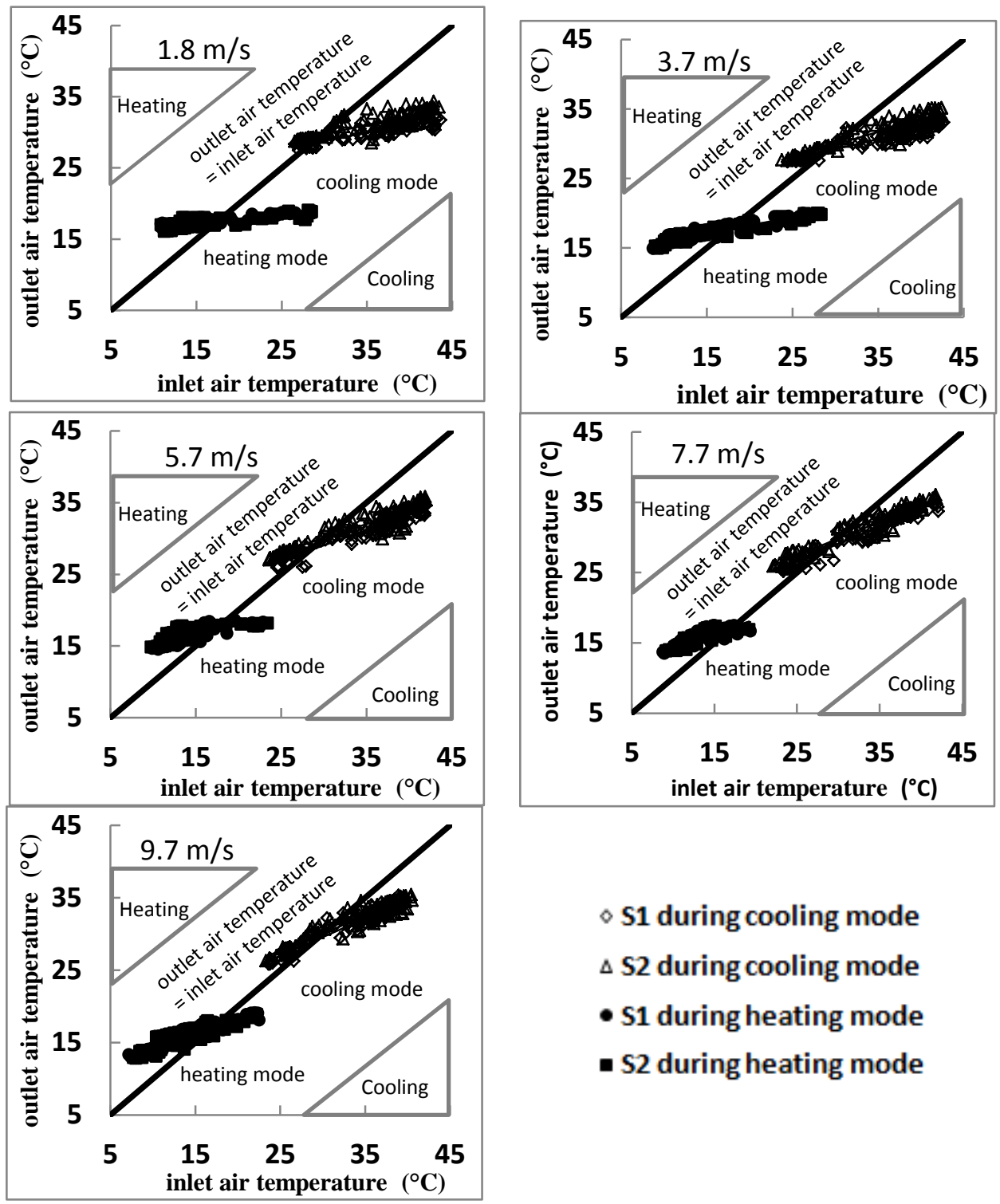

$\diamond$ S1 during cooling mode

$\triangle$ S2 during cooling mode

- s1 during heating mode

- S2 during heating mode

Figure 10 : The relationship between inlet and outlet air temperatures for both systems $\mathrm{S} 1$ and $\mathrm{S} 2$ in cooling and heating modes at various air velocities for all operating durations.

During heating mode an undesired cooling effect occurred at operating duration 22 of hours. In addition increasing air velocity causes a slight reduction in cooling and heating actions for both systems and all operating durations. 


\section{SUMMARY AND CONCLUSION}

The present study aimed to evaluate the thermal potential of two earth tube heat exchanger systems in air temperature moderating in delta region. Two earth tube heat exchanger systems were installed at the research farm faculty of agriculture, Kafrelsheikh University, Kafrelsheikh governorate, Egypt. The experimental work was carried out during the period from August 2014 to February 2015. In the first system (S1) the heat transfer takes place across the tube wall material (PVC). The second system (S2) provides an additional water layer and another tube wall material (PVC) for the heat transfer to take place.

Both systems S1 and S2 were connected to $0.75 \mathrm{~kW}$ air blowing system, valves and a transverse tube above ground level in a manner leads to begin the investigation of the whole experimental systems. Five air velocities namely $1.8,3.7,5.7,7.7$ and $9.7 \mathrm{~m} / \mathrm{s}$ and four operating durations namely $6,9,12$ and 22 hours were investigated under cooling and heating modes. The performance of both systems was evaluated in terms of temperature reduction / rise, thermal energy rate removed / added and coefficient of performance (COP) under Cooling / heating modes and the following is the main conclusions :

\section{Cooling mode}

For $\mathrm{S} 1$, the maximum temperature reduction of about $12.65{ }^{\circ} \mathrm{C}$ was achieved, at air velocity $1.8 \mathrm{~m} / \mathrm{s}$ and 12 hours operating duration. The maximum thermal energy rate removed was $671.8 \mathrm{~W}$ at air velocity 7.7 $\mathrm{m} / \mathrm{s}, 12$ hours operating duration and the corresponding COP was 4.02. For S2 the maximum thermal energy rate removed was $679.9 \mathrm{~W}$ at air velocity $9.7 \mathrm{~m} / \mathrm{s}, 22$ operating duration and the corresponding COP was 3.96. Regarding COP, the effect of increasing air flow rate was predominant than the effect of temperature reduction. Maximum, minimum outlet air temperatures during day time were 32.97, 30.16 and $34.48,31.55{ }^{\circ} \mathrm{C}$ for $\mathrm{S} 1$ and $\mathrm{S} 2$, respectively. It was pronounced that $\mathrm{S} 1$ proves superior potential compared to $\mathrm{S} 2$ and it costs less as well. Both 
systems contribute in air temperature control declares in diminishing its amplitude. However some undesired heating effect were existed at the longest operating duration. A negative relationship between air velocity and the desired cooling action in terms of temperature reduction / rise were found due to the shortness in contact time during which heat transfer takes place.

\section{Heating mode}

Maximum temperature rise and maximum thermal energy rate added for S1 were $6.27{ }^{\circ} \mathrm{C}$ at velocity $3.7 \mathrm{~m} / \mathrm{s}, 12$ hours operating duration and $629.7 \mathrm{~W}$ at air velocity $9.7 \mathrm{~m} / \mathrm{s}, 12$ hours operating duration respectively and the corresponding COP was 3.67. For S2 the maximum thermal energy rate added was $573.7 \mathrm{~W}$ at air velocity $9.7 \mathrm{~m} / \mathrm{s}, 12$ hours operating duration and the corresponding was COP 3.34. Again the contact time plays a major role in heating action as well. Maximum, minimum outlet air temperatures during heating mode were 16.73, 15.85 and $17.16,15.77{ }^{\circ} \mathrm{C}$ for $\mathrm{S} 1$ and $\mathrm{S} 2$, respectively. However, undesired cooling effects were observed when operating duration was extended. Generally it was evident that the heating potential for both systems was almost the same with a relevant advantage for $\mathrm{S} 1$. As in cooling mode the contribution in temperature control was existed as well. The expectation of the suggested system S2 in extending the positive action time was not clear. Therefore one can concluded that the traditional system S1 has enough thermal potential in air temperature moderating in addition to its low cost and expected a longest non- life time.

\section{REFERENCES}

Al-Ajmi, F. ; D.L. Lovedayb, and V.I. Hanbyc. 2006. The cooling potential of earth-air heat exchangersfor domestic buildings in a desert climate. Building and Environment $41: 235-244$.

Ascione, F.; L. Bellia and F. Minichiello. 2011. Earth-to-air heat exchangers for Italian climates. Renewable Energy 36 : 21772188. 
Badescu, V. 2007. Simple and accurate model for the ground heat exchanger of a passive house. Renewable Energy 32 : 845-855.

Bansal, V. ; R. Misra, G. D. Agrawal, and J. Mathur. 2009. Performance analysis of earth-pipe-air heat exchanger for winter heating. Energy and Buildings 41 : 1151-1154.

Bansal, V. ; R. Misra, G. D. Agrawal, and J. Mathur. 2010. Performance analysis of earth-pipe-air heat exchanger for summer cooling. Energy and Buildings 42 : 645-648.

Darkwa, J.; G. Kokogiannakis, C.L. Magadzire, and K. Yuan. 2011. Theoretical and practical evaluation of an earth-tube (E-tube) ventilation system. Energy and Buildings 43 : 728-736.

Dubey. H. ; B. kothi and K. Choudhary. 2016. Performance analysis of earth tube heat exchanger. International Journal of Engineering Science \& Research Technology. (IJESRT), 5(7): 323-331.

Ghosal, M. K. ; and G. N. Tiwari. 2006 . Modeling and parametric studies for thermal performance of an earth to air heat exchanger integrated with a greenhouse. Energy Conversion and Management 47 : 1779-1798.

Ghosal, M. K. ; G. N. Tiwari, and N. S. L. Srivastava. 2004 . Thermal modeling of a greenhouse with an integrated earth to air heat exchanger: an experimental validation. Energy and Buildings 36 : 219-227.

Kassem, A. M. M. 1999. Possibilities of using soil heat as renewable source for conditioning greenhouse. Ph.D. Thesis, Agric. Mech. Department, Faculty of Agriculture, Mansoura University.

Lee, K. H. ; and R. K. Strand. 2008. The cooling and heating potential of an earth tube system in buildings. Energy and Buildings $40: 486-$ 494. 
Mihalakakou, G. 2003. On the heating potential of a single buried pipe using deterministic and intelligent techniques. Renewable Energy 28 : 917-927.

Mihalakakou, G.; M. Santamouris and D. Asimakopouris. 1994. On the cooling potential of earth to air heat exchangers. Energy Convers. Mgmt 35 (5) : 395-402.

Mongkon, S.; S. Thepa, P. Namprakai and N. Pratinthong. 2013. Cooling performance and condensation evaluation of horizontal earthtube system for the tropical greenhouse. Energy and Buildings 66 : 104111.

Ozgener, O. and L. Ozgener. 2010 a. Exergetic assessment of EAHEs for building heating in Turkey: A greenhouse case study. Energy Policy 38 : 5141-5150.

Ozgener, L. and O. Ozgener. 2010 b. Energetic performance test of an underground air tunnel system for greenhouse heating. Energy 35 : 4079-4085.

Ozgener, O.; L. Ozgener and D. Y. Goswami. 2011. Experimental prediction of total thermal resistance of a closed loop EAHE for greenhouse cooling system. International Communications in Heat and Mass Transfer $38: 711-716$.

Pfafferott, J. 2003. Evaluation of earth-to-air heat exchangers with a standardized method to calculate energy efficiency. Energy and Buildings 35: 971-983.

Vaz, J.; M. A. Sattler, E. D. dos Santos and L. A. Isoldi. 2011. Experimental and numerical analysis of an earth-air heat exchanger. Energy and Buildings 43 : 2476-2482.

Wu, H.; S. Wang and D. Zhu. 2007. Modelling and evaluation of cooling capacity of earth-air-pipe systems. Energy Conversion and Management $48: 1462-1471$. 
Yoon, G.; H. Tanaka and M. Okumiya. 2009. Study on the design procedure for a multi-cool/heat tube system. Solar Energy 83 : $1415-1424$.

\section{الملخص العربى}

\section{الامكانيه الحراريه لمنظومه تبادل حرارى بين الهواء والتربه فى تعديل درجه حراره الهواء}

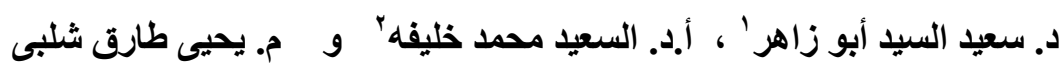

تم دراسه امكانيه استخدام الانابيب المدفونه بالتربه كمنظومه تبادل حرارى بين الهواء و التربه فى منطقه الدلتا تجريبيا باستخدام نظامين مختلفين. نم تركيب النظامين فى المز عه البحثيه بكليه

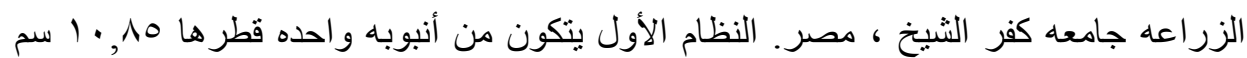

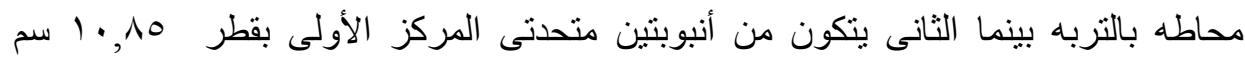

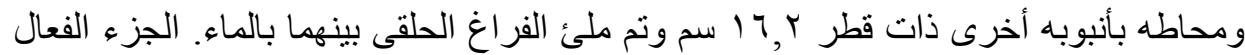

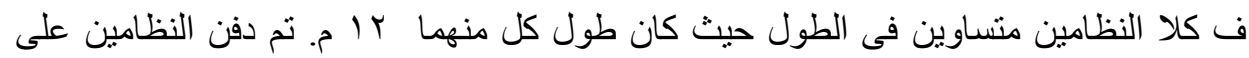
عمق 0V, · م تحت سطح التربه على بعد ه م كمسافه بينيه بينهما. تم استخدام شاحن هو اء بقدره

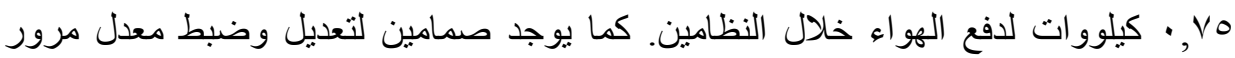
الهو اء فى النظامين للحصول على نفس سرعات مرور الهو اء فى كلا النظامين وذللك بمساعده

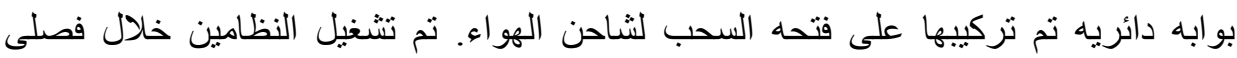

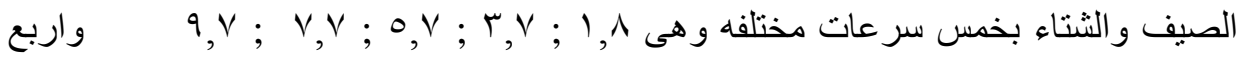

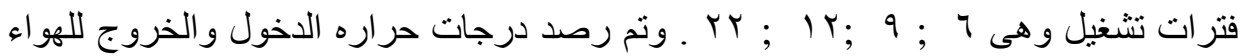
وكذلك الرطوبه النسبيه له، درجات حراره الهو اء المحبطه. كما تم رصد والتأكد من سرعات

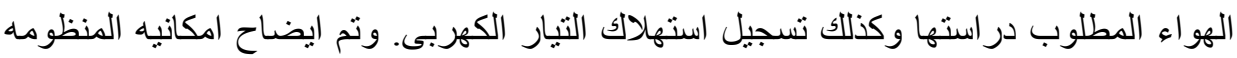
المقترحه فى تعديل درجه حراره الهو اء عن طريق انخفاض / ارتفاع درجه الحراره ، معدل

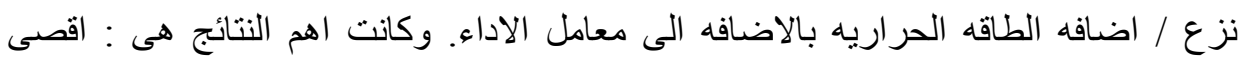

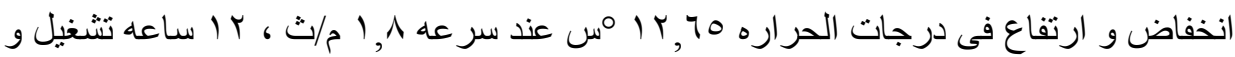

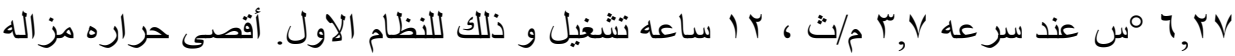

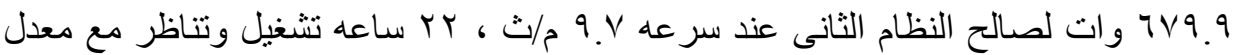

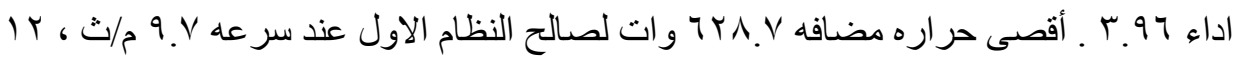

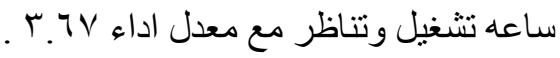

' مدرس الهندسه الزراعيه ـ قسم الهندسه الزراعيه ـ كليه الزراعه ـ ـ جامعاه كفر الشيخ.

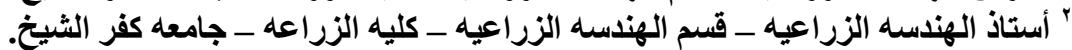

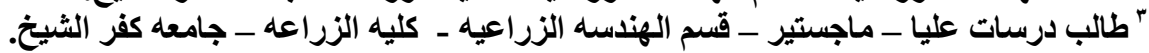


وجد ان مدى تغير حر اره الخروج خلال اليوم صغير مما يدل على وجود تحكم بيئى جيد. كلما

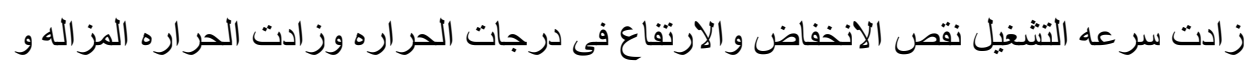

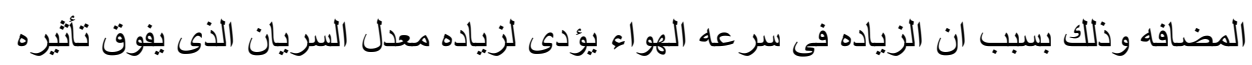

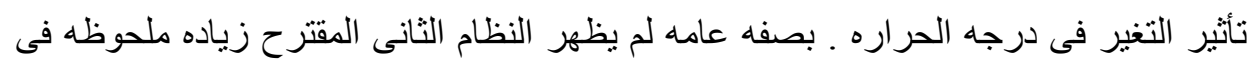

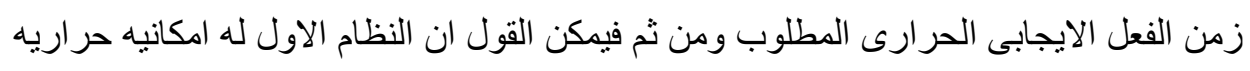

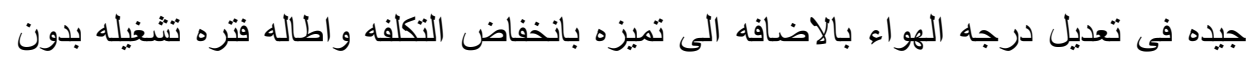
اعطال متوقعه مقارنه بالنظام الثانى. 